\title{
$\mathrm{R} 744$ 를 2차 냉매로 사용하는 내부열교환기 부착 $\mathrm{R} 404 \mathrm{~A}$ 냉동시스템의 성능 분석
}

\section{Performance Analysis of R404A Refrigeration System with Internal Heat Exchanger Using R744 as a Secondary Refrigerant}

오후규 $\left(\mathrm{Hoo}_{-} \mathrm{Kyu} \mathrm{Oh}\right)^{1}$, 손창효 (Chang-Hyo Son $)^{1}$, 이문빈(Wen-Bin Yi) ${ }^{2}$, 전민주(Min-Ju Jeon $)^{1+}$ ${ }^{1}$ 부경대학교 냉동공조공학과, ${ }^{2}$ 부경대학교 냉동공조공학과 대학원

${ }^{1}$ Department of Refrigeration and Air-conditioning Engineering, Pukyong National University, Busan 608-739, Republic of Korea

${ }^{2}$ Graduate School of refrigeration and Air-conditioning Engineering, Pukyong National University, Busan 608-739, Republic of Korea

(Received July 18, 2013; revision received August 21, 2013)

\begin{abstract}
A thermodynamic analysis of the R404A refrigeration system with an internal heat exchanger using R744 as a secondary refrigerant is presented in this paper to optimize the design for operating parameters of the system. The main results are summarized as follows: The COP increases with increasing subcooling and superheating degree of R404A, internal heat exchanger and compression efficiency of the R404A cycle and evaporating temperature of the R744 cycle and decreasing temperature difference of the cascade heat exchanger and condensing temperature of the R404A cycle. The mass flow ratio decreases with increasing evaporating temperature of the R744 cycle and internal heat exchanger efficiency of the R404A cycle and decreasing subcooling and superheating degree of the R744 cycle, temperature difference of the cascade heat exchanger and condensing temperature of the R404A cycle.
\end{abstract}

Key words Secondary refrigeration system(2차 냉동시스템), Internal heat exchanger(내부열교환기), $\operatorname{COP}($ 성능계수), Performance analysis(성능 분석)

† Corresponding author, E-mail: mini7970@nate.com

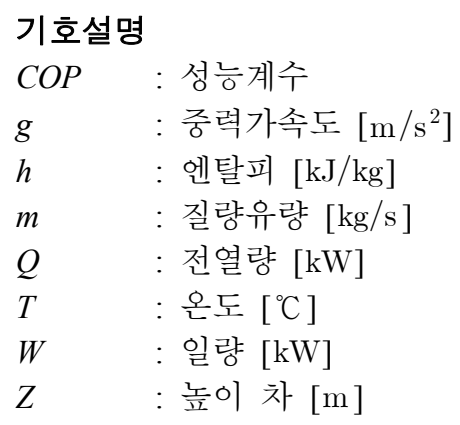

\section{그리스 문자}

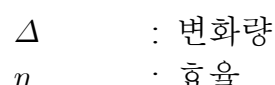

$\eta \quad$ : 효율

하첨자

$R 744$ : 이산화탄소

$\begin{array}{ll}R 404 A & : \text { 냉매 } 404 \mathrm{~A} \\ c & : \text { 압축 } \\ c a s & : \text { 캐스케이드 열교환기 } \\ c o n & : \text { 응축 } \\ e & : \text { 증발 } \\ I H X & : \text { 내부열교환기 } \\ m & : \text { 기계 } \\ o p t & : \text { 최적 } \\ p & : \text { 펌프 } \\ s u c & : \text { 과냉도 } \\ s u h & : \text { 과열도 }\end{array}$

1. 서 론

최근 환경문제가 우리의 생태계를 위협하면서 현대 인들은 환경문제로부터 자유로울 수 없게 되었다. 냉 
매에 대해서도 R11, R12 등의 대체 냉매로 단일 혹은 여러 가지 혼합냉매들이 개발되었으나 지구온난화지 수와 오존파괴지수로부터 자유로울 수 없다는 것이 알 려지면서 일본, 미국, 유럽은 일찍이 자연냉매에 대하 여 연구해오고 있다. 그중에서도 R744에 대한 연구가 주축으로 진행되고 있다. 한국은 2000년 전후로 R744 에 대한 연구가 시작되었으나 아직도 일본, 미국, 유럽 에 비하여 연구가 많이 부족하다.

R744를 이용하는 최근의 연구는 크게 세 가지로 나눌 수 있다. 캐스케이드 시스템, ${ }^{(1)} 2$ 차 냉매 시스템, ${ }^{(2)}$ 초임 계 사이클 ${ }^{(3)}$ 이 그것이다. 초임계 사이클 ${ }^{(4-6)}$ 이나 캐스케 이드 시스템 ${ }^{(7)}$ 에 대한 연구는 국내에서도 진행되어왔지 만 2차 냉매 시스템에 대해서는 다소 부족한 실정이다. 2차 냉매로서 단상 유체들이 많이 이용되었지만 최근에 는 잠열을 이용할 수 있으며, 저온에서 점성계수가 낮은 R744나 R717에 대한 연구가 이루어지고 있다. 또한 유 럽을 중심으로 냉매 누출에 대한 연구들도 이루어지고 있는데, ${ }^{(8,9)} 1993$ 년 노르웨이에서 상업용 장치로부터 년 간 전체 $30 \%$ 의 냉매가 누출되고 있다고 보고되었다. ${ }^{\left({ }^{8}\right)}$ 자연냉매들 중에서 독성이 없고 폭발성이 없는 R744에 더욱 주목할 수밖에 없는 이유가 여기에 있다 하겠다.

따라서, 본 연구에서는 R744를 2차 냉매로 사용하는 냉동사이클에 대한 성능분석과 최적의 냉매 충전량에 대한 기초자료를 제공하고자 한다.

\section{2. 수치 해석}

본 논문에서 사용되는 냉매의 열역학적 물성치와 성 능 분석은 EES(Engineering Equation Solver, v8.574-3D, 2010) 소프트웨어를 이용하여 계산하였다. R744를 2차 냉매로 사용하는 내부열교환기 부착 R404 A 냉동시스 템의 성능 분석을 위해 다음과 같이 가정하였다.

$\mathrm{R} 404 \mathrm{~A}$ 냉동사이클의 압축기 내 냉매는 단열압축과
정이고, 기계효율 $\left(\eta_{m}\right)$ 은 통상의 경우를 예상하여 0.8 이 라 가정한다.

열교환기(R744 증발기, 캐스케이드 열교환기, R404A 응축기, 내부열교환기)와 배관 내 냉매 압력강하와 열 손실은 무시한다.

R404 A 냉동사이클의 팽창밸브 내 냉매는 단열팽창 인 등 엔탈피과정이다.

운동에너지의 변화는 없는 것으로 가정한다.

$\mathrm{R} 744$ 냉매 펌프의 효율 $\left(\eta_{p}\right)$ 은 0.4 , 입 - 출구 높이 차 (Z)는 $1.4 \mathrm{~m}, \mathrm{R} 744$ 질량유량 $\left(m_{R 744}\right)$ 은 $0.1 \mathrm{~kg} / \mathrm{s}$ 로 고정 한다.

열교환기와 배관 내 냉매 압력강하와 열손실은 무 시하므로 R744 증발온도와 응축온도는 동일하다.

위에 언급한 가정을 토대로 질량유량, 압축일량, 증 발기와 응축기, 캐스케이드와 내부열교환기의 전열량 은 다음의 식으로 계산한다.

- 질량 보존식

$$
\sum_{i n} m=\sum_{o u t} m
$$

- 에너지 보존식

$$
Q-W+\sum_{i n} m h-\sum_{o u t} m h=0
$$

Fig. 1은 본 연구에서 적용하는 간접 냉동시스템의 개략도이고, 이 연구에 필요한 식들은 Table 1에 정리 하였다. 캐스케이드 열교환기 내 R744와 R404A의 전 열량 $\left(Q_{c a s}\right)$ 과 R744 증발열량은 위의 가정에서 주위로 의 열손실 및 압력강하는 없다고 하였으므로 아래의 식(3)과 식(4)로 나타낼 수 있다.

Table 1 Energy and mass balance equation for each component of indirect cooling system using R744 as a secondary

\begin{tabular}{|c|c|c|c|}
\hline Cycle & Component & Energy & Mass \\
\hline \multirow{6}{*}{$\begin{array}{l}\text { R404A refrigeration cycle } \\
\text { (R404 A circuit) }\end{array}$} & Evaporator $(5 \rightarrow 6)$ & $Q_{R 404 A, e}=m_{R 404 A}\left(h_{6}-h_{5}\right)$ & \multirow{6}{*}{$\begin{array}{l}m_{R 404 A}=m_{1} \\
=m_{2}=m_{3} \\
=m_{4}=m_{5} \\
=m_{6}\end{array}$} \\
\hline & Internal heat exchanger $(6 \rightarrow 1)$ & $Q_{I H X}=m_{R 404 A}\left(h_{1}-h_{6}\right)$ & \\
\hline & Compressor $(1 \rightarrow 2)$ & $W_{c}=m_{R 404 A}\left(h_{2}-h_{1}\right) / \eta_{c} \eta_{m}$ & \\
\hline & Condenser $(2 \rightarrow 3)$ & $Q_{R 404 A, \text { con }}=m_{R 404 A}\left(h_{2}-h_{3}\right)$ & \\
\hline & Internal heat exchanger $(3 \rightarrow 4)$ & $Q_{I H X}=m_{R 404 A}\left(h_{3}-h_{4}\right)$ & \\
\hline & Expansion valve $(4 \rightarrow 5)$ & $h_{4}=h_{5}$ & \\
\hline \multirow{3}{*}{$\begin{array}{l}\text { R744 liquid circulating } \\
\text { pump cycle } \\
\text { (R744 circuit) }\end{array}$} & Evaporator $(9 \rightarrow 7)$ & $Q_{R 744, e}=m_{R 744}\left(h_{7}-h_{9}\right)$ & \multirow{3}{*}{$\begin{array}{l}m_{R 744}=m_{7} \\
=m_{8}=m_{9}\end{array}$} \\
\hline & Condenser $(7 \rightarrow 8)$ & $Q_{R 744, \mathrm{con}}=m_{R 744}\left(h_{7}-h_{8}\right)$ & \\
\hline & $\operatorname{Pump}(8 \rightarrow 9)$ & $W_{p}=m_{R 744}(g \cdot Z) / \eta_{p}$ & \\
\hline
\end{tabular}
refrigerant 


$$
Q_{c a s}=Q_{R 744, e}=Q_{R 744, c}=Q_{R 404 A, e}
$$

$$
\begin{aligned}
Q_{c a s} & =m_{R 744}\left(h_{7}-h_{9}\right)=m_{R 744}\left(h_{7}-h_{8}\right) \\
& =m_{R 404 A}\left(h_{6}-h_{5}\right)
\end{aligned}
$$

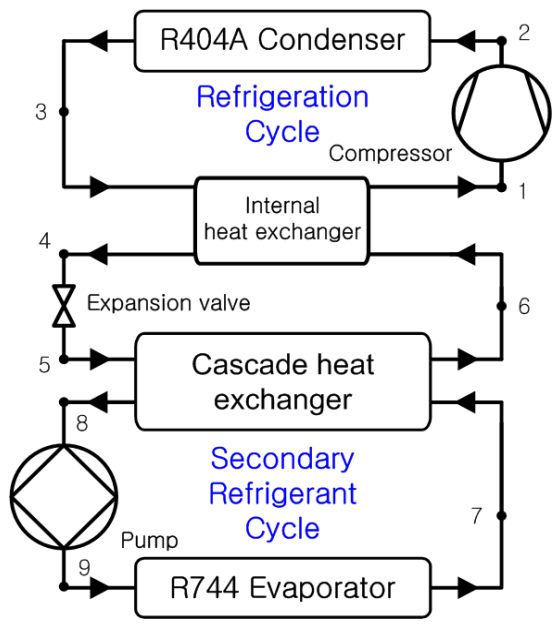

Fig. 1 Schematic diagram of indirect cooling system using R744 as a secondary refrigerant.

여기서 $Q_{R 744,}$ 는 $\mathrm{R} 744$ 증발열량이고, $Q_{R 744, c o n}$ 은 $\mathrm{R} 744$ 응축열량이며, $Q_{R 404 A,} e$ 는 $\mathrm{R} 404 \mathrm{~A}$ 증발열량이다. $\mathrm{R} 404 \mathrm{~A}$ 냉동사이클의 성능계수 $(\mathrm{COP})$ 는 $\mathrm{R} 404 \mathrm{~A}$ 증발 열량 $\left(Q_{R 404 A, e}\right)$ 과 압축일량 $\left(W_{c}\right)$ 으로부터 아래의 식(5) 로 계산한다.

$$
\mathrm{COP}=\frac{Q_{R 404 A, e}}{W_{c}}
$$

여기서 압축일량은 아래의 식(6)으로 계산하며,

$$
W_{c}=\frac{m_{R 404 A}\left(h_{2}-h_{1}\right)}{\eta_{c} \eta_{m}}
$$

또한 질량유량비 $\left(m_{R 404 A} / m_{R 744}\right)$ 는 식(4)로부터 아래 의 식(7)로 계산한다.

$$
\frac{m_{R 404 A}}{m_{R 744}}=\frac{h_{7}-h_{9}}{h_{6}-h_{5}}=\frac{h_{7}-h_{8}}{h_{6}-h_{5}}
$$

여기서 질량유량비는 R404A 냉동사이클 내 최적의 냉매 충전량에 대한 기초자료가 된다.

각 부분의 에너지와 질량계산은 Table 1 에 나타내고 Table 2에는 본 연구에서 사용되는 성능 분석 범위를 나타내었다. Table 1과 2로부터 나온 분석값을 이용하
Table 2 Analysis conditions

\begin{tabular}{l|l}
\hline \multicolumn{1}{c|}{ Items } & \multicolumn{1}{|c}{ Conditions } \\
\hline$\eta_{c}$ & $0.5,0.6,0.7,0.8^{*}, 0.9,1.0$ \\
\hline$\eta_{I H X}$ & $0.5,0.6,0.7,0.8^{*}, 0.9,1.0$ \\
\hline$T_{R 404 A, \text { con }}$ & $30^{*}, 35,40,45,50\left[{ }^{\circ} \mathrm{C}\right]$ \\
\hline$\Delta T_{R 404 A, \text { suc }}$ & $0{ }^{*}, 5,10,15,20\left[{ }^{\circ} \mathrm{C}\right]$ \\
\hline$\Delta T_{R 404 A, \text { suh }}$ & $0{ }^{*}, 5,10,15,20\left[{ }^{\circ} \mathrm{C}\right]$ \\
\hline$T_{R 744, e}$ & $-20^{*},-15,-10,-5,0\left[{ }^{\circ} \mathrm{C}\right]$ \\
\hline$\Delta T_{R 744, \text { suh }}$ & $0^{*}, 5,10,15,20\left[{ }^{\circ} \mathrm{C}\right]$ \\
\hline$\Delta T_{R 744, \text { suc }}$ & $0,5,10,15,20\left[{ }^{\circ} \mathrm{C}\right]$ \\
\hline$\Delta T_{\text {cas }}$ & $1,3,5{ }^{*}, 7,9\left[{ }^{\circ} \mathrm{C}\right]$ \\
\hline
\end{tabular}

${ }^{*}$ Standard condition.

여 $\mathrm{R} 404 \mathrm{~A}$ 냉동사이클의 성능에 영향을 미치는 R744 증발온도 $\left(T_{R 744, e}\right), \mathrm{R} 744$ 과냉도 $\left(\Delta T_{R 744, s u c}\right)$ 와 과열도 $\left(\Delta T_{R 744, s u h}\right)$, 케스케이드 온도차 $\left(\Delta T_{c a s}\right), \mathrm{R} 404 \mathrm{~A}$ 과냉도 $\left(\Delta T_{R 404 A, s u c}\right)$ 와 과열도 $\left(\Delta T_{R 404 A, s u h}\right), \mathrm{R} 404 \mathrm{~A}$ 응축온도 ( $\left.T_{R 404 A, c o n}\right)$, 내부열교환기 효율 $\left(\eta_{I H X}\right)$ 과 압축효율 $\left(\eta_{c}\right)$ 에 대한 영향을 살펴보고자 한다.

\section{3. 결과 및 고찰}

\section{1 과냉도와 과열도에 따른 영향}

Fig. 2와 Fig. 3은 Table 2에 나타낸 고정된 표준 상태 에서 R744의 과냉도 혹은 과열도, R404A의 과냉도 혹 은 과열도 따른 $\mathrm{COP}$ 와 질량유량비를 나타낸 것이다.

Fig. 2와 Fig. 3에서 R744 루프의 과냉도 혹은 과열 도만 $5^{\circ} \mathrm{C}$ 씩 증가시킴에 따라 $\mathrm{COP}$ 는 동일한 값으로 일정하나 질량유량비는 각각 약 $3.2 \sim 3.8 \%, 1.8 \sim 2.2 \%$ 씩 증가하는 것을 확인할 수 있다. 이는 R744 루프의 과냉도나 과열도를 증가시킴에 따라 식(3)에서와 같이 R744 증발/응축 전열량과 캐스케이드 열교환기의 전 열량은 동일하게 증가하나 $\mathrm{R} 404 \mathrm{~A}$ 냉동사이클의 조건 (증발온도, 응축온도, 과냉도, 과열도, 내부열교환기효 율, 압축효율)은 동일하므로 전열량 증가에 따른 $\mathrm{R} 404 \mathrm{~A}$ 의 질량유량만 증가하기 때문이라 하겠다.

또한 $\mathrm{R} 404 \mathrm{~A}$ 과냉도만 $5^{\circ} \mathrm{C}$ 씩 증가시킴에 따라 $\mathrm{COP}$ 는 약 $4.3 \sim 4.5 \%$ 씩 증가하며 질량유량비는 약 $2.3 \sim$ $2.7 \%$ 씩 감소한다. 이는 $\mathrm{R} 404 \mathrm{~A}$ 과냉도를 $5{ }^{\circ} \mathrm{C}$ 씩 증가함 에 따라 식(3), 식(4)에서 $h_{5}$ 값의 감소로 $\left(h_{6}-h_{5}\right)$ 이 증 가하고 표준 상태의 시스템 내 R404A 증발열량은 변 화가 없기 때문에 질량유량비가 감소하게 된다. 또한, 식(6)에서 다른 변수들 $\left(h_{1}, h_{2}, \eta_{c}, \eta_{m}\right)$ 의 변화 없이 질 량유량비의 감소에 따라 압축일량은 약 $4.1 \sim 4.3 \%$ 씩 


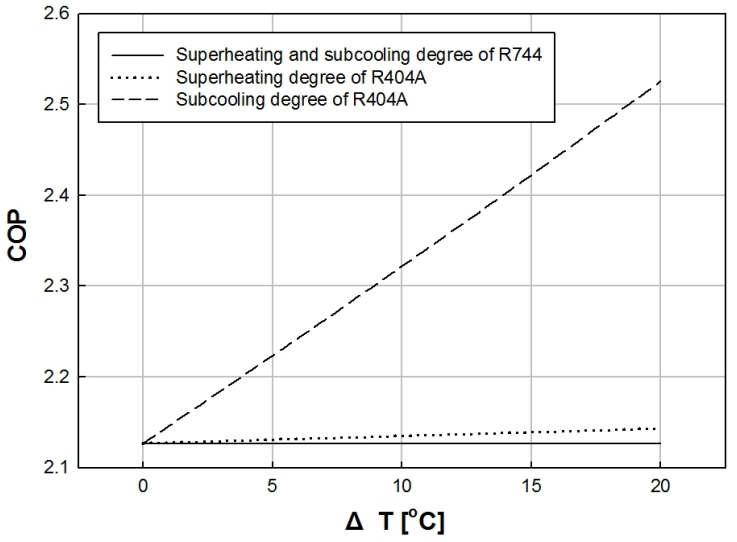

Fig. 2 Variation of COP with respect to superheating and sub cooling degree in indirect cooling system.

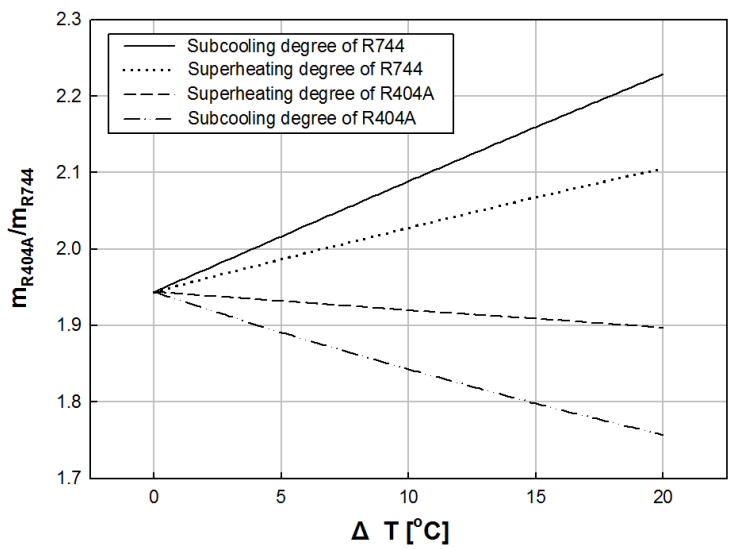

Fig. 3 Variation of R404A and R744 mass ratios with respect to superheating and subcooling degree in indirect cooling system.

감소하게 되어 결국 $\mathrm{COP}$ 가 증가하게 되는 것이다.

그리고 $\mathrm{R} 404 \mathrm{~A}$ 과열도만 $5^{\circ} \mathrm{C}$ 씩 증가시킴에 따라 $\mathrm{COP}$ 가 약 $0.19 \%$ 씩 증가하며 질량유량비는 약 $0.6 \%$ 씩 감소한다. 그 이유는 R404A 과열도 증가에 따라 $\mathrm{P}-\mathrm{h}$ 선도상에서 $h_{6}$ 의 값이 커지고 $\left(h_{6}-h_{5}\right),\left(h_{2}-h_{1}\right)$ 이 증가 하나, 식(4) 식(6)에서 $\left(h_{6}-h_{5}\right)$ 의 증가율이 $\left(h_{2}-h_{1}\right)$ 의 증가율 보다 조금 더 크기 때문에 $\mathrm{COP}$ 가 증가하게 된다. 여기서 일반적으로 $\mathrm{R} 404 \mathrm{~A}$ 루프의 과열도가 증 가하면 $\mathrm{R} 404 \mathrm{~A}$ 증발열량의 증가율보다 압축효율 감소 로 인한 압축일량의 증가율이 더 크기 때문에 $\mathrm{COP}$ 가 감소하게 된다. 그러나 본 연구에서는 압축효율과 기 계효율을 포함한 고정된 표준상태에서 R404A의 과열 도만의 영향을 나타낸 비교이기 때문에 다른 경향을 나타내었다. 반면에 질량유량비는 식(3), 식(4)로부터 표 준 상태의 시스템 내 R404A 증발열량은 변화가 없기 때문에 질량유량비가 약 $0.6 \%$ 씩 감소하게 된다.

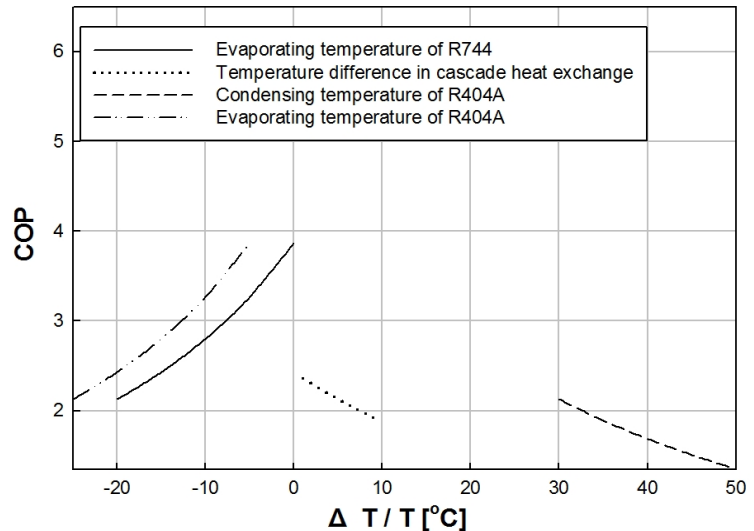

Fig. 4 Variation of COP with respect to temperature of each heat exchanger and temperature difference of cascade heat exchanger.

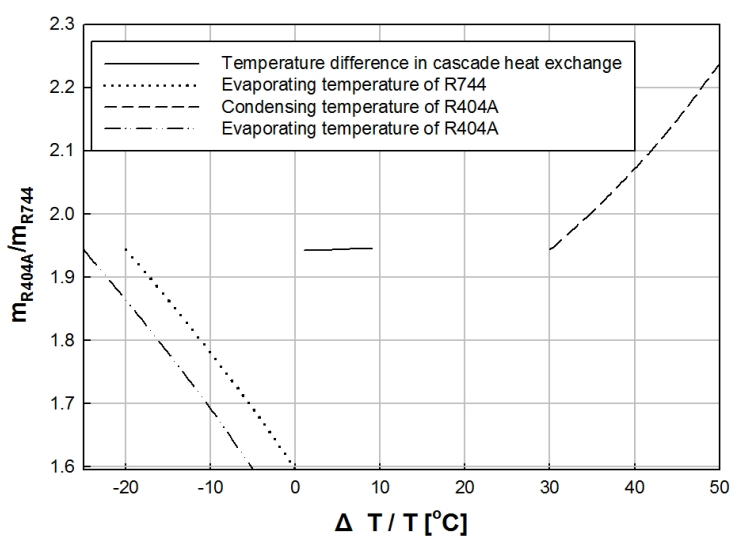

Fig. 5 Variation of R404A and R744 mass ratios with respect to temperature of each heat exchanger and temperature difference of cascade heat exchanger.

\section{2 각 열교환기 온도와 캐스케이드 열교환기의 온도차에 따른 영향}

Fig. 4와 Fig. 5는 표준 상태에서 R744 증발온도와 캐스케이드 온도차, 그리고 R404A 증발/응축온도 에 따른 $\mathrm{COP}$ 와 질량유량비를 나타낸 것이다.

Fig. 4와 Fig. 5에서 R744 증발온도와 캐스케이드 온 도차, 그리고 R404A 증발/응축온도의 변화에 따라 $\mathrm{COP}$ 와 질량유량비는 반대 경향을 보임을 알 수 있다. 즉, $\mathrm{R} 744$ 와 $\mathrm{R} 404 \mathrm{~A}$ 의 증발온도가 $5^{\circ} \mathrm{C}$ 씩 증가함에 따라 $\mathrm{COP}$ 는 약 $14.3 \sim 18.4 \%$ 씩 증가하나 질량유량비는 약 4.1 5.7\%씩 감소한다. 캐스케이드 온도차와 R404A 응축 온도는 각각 $2^{\circ} \mathrm{C}, 5^{\circ} \mathrm{C}$ 씩 증가함에 따라 $\mathrm{COP}$ 는 약 $4.9 \sim$ $5.2 \%, 10.5 \sim 11.2 \%$ 씩 감소하나 질량유량비는 각각 약 $0.05 \%, 3.1 \sim 4.1 \%$ 씩 소폭 증가한다. 


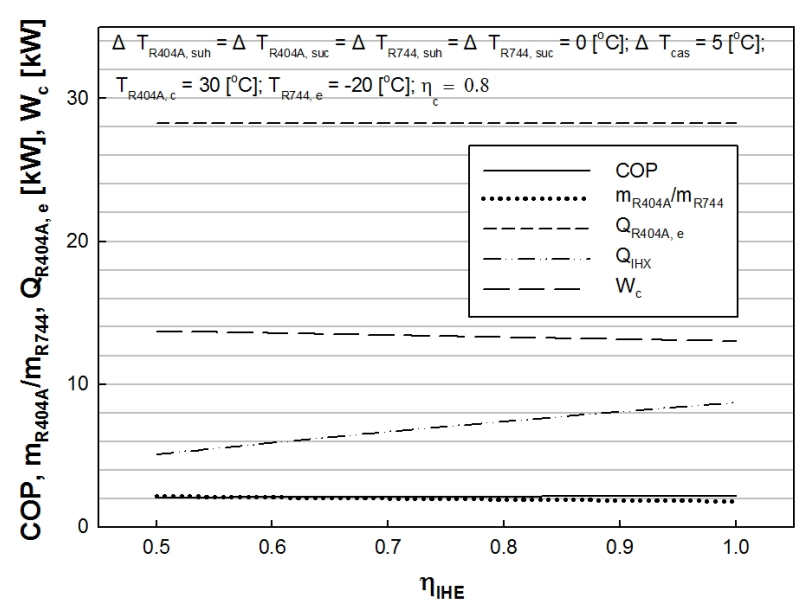

Fig. 6 Effect of internal heat exchanger efficiency on R404A refrigeration cycle.

이는 $\mathrm{R} 744$ 와 $\mathrm{R} 404 \mathrm{~A}$ 의 증발온도가 $5{ }^{\circ} \mathrm{C}$ 씩 증가함에 따라 R404 A 증발열량과 압축일량은 감소하는데, R404 $\mathrm{A}$ 증발열량이 약 $4.1 \sim 5.9 \%$ 감소하는 것에 비해 압축 일량은 약 $16 \sim 20.5 \%$ 로 큰 폭으로 감소하기 때문이다. 또한, 캐스케이드 온도차와 R404 A 응축온도가 각각 2 ${ }^{\circ} \mathrm{C}, 5^{\circ} \mathrm{C}$ 씩 증가함에 따라 $\mathrm{R} 404 \mathrm{~A}$ 증발열량은 동일하 나 압축일량이 각각 약 $5.1 \sim 5.5 \%, 11.7 \sim 12.6 \%$ 씩 증가 하기 때문이다.

\section{3 내부열교환기와 압축기 효율에 따른 영향}

Fig. 6은 표준 상태에서 내부열교환기 효율 $\left(\eta_{I H X}\right)$ 변 화에 따른 $\mathrm{R} 404 \mathrm{~A}$ 냉동사이클의 $\mathrm{COP}$, 질량유량비, 증발 열량, 내부열교환기 전열량, 압축일량을 나타내고 있다.

Fig. 6에서 내부열교환기 효율이 $10 \%$ 씩 증가함에 따 라 $\mathrm{COP}$ 는 약 $1 \%$ 씩 증가하고 질량유량비는 $3.1 \sim 3.5 \%$ 씩 감소하며 R404A 증발열량은 $28.24 \mathrm{~kW}$ 로 일정하다. 또한 압축일량은 약 $1 \%$ 씩 감소하며 내부열교환기 전 열량은 약 $8 \sim 16 \%$ 씩 증가한다. 이는 $\mathrm{COP}$ 의 소폭 증가 는 내부열교환기 효율이 증가할수록 식(6)의 $h_{1}$ 이 증대 되어 압축일량이 감소하기 때문인 것으로 판단된다.

Fig. 7은 표준 상태에서 압축효율 변화에 따른 R404A 냉동사이클의 $\mathrm{COP}$, 질량유량비, 증발열량, 내부열교환 기 전열량, 압축일량을 나타내고 있다.

Fig. 7 에서 압축효율이 $10 \%$ 씩 증가함에 따라 $\mathrm{COP}$ 는 약 $11 \sim 20 \%$ 씩 증가하고 질량유량비와 R404A 증발열 량은 각각 약 $1.94,28.24 \mathrm{~kW}$ 로 일정하다. 또한 압축일 량은 약 $10 \sim 16.7 \%$ 씩 감소하며 내부열교환기 전열량 은 $7.39 \mathrm{~kW}$ 로 일정하다. 이는 질량유량비와 $\mathrm{R} 404 \mathrm{~A}$ 증 발열량과는 무관하게 압축효율의 증대에 따라 압축일 량만 감소하기 때문인 것으로 판단된다.

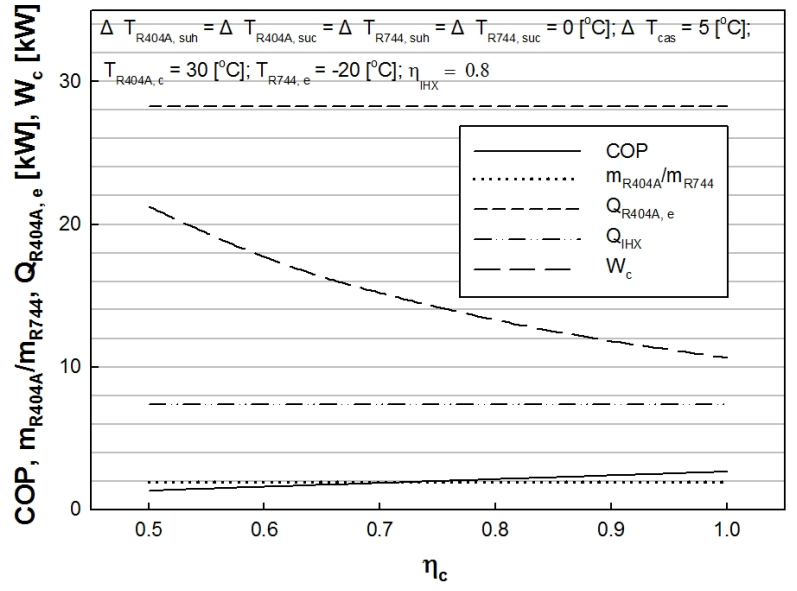

Fig. 7 Effect of compression efficiency on R404A refrigeration cycle.

\section{4 질량유량비와 $\mathrm{COP}$ 관계 비교}

Fig. 2 Fig. 7에서 표준 상태에서 각 변수에 따른 $\mathrm{COP}$ 와 질량유량비를 나타내고 있다. 이중에서 R744 과냉도와 과열도, 압축효율에 따른 영향 질량유량비에 대해서는 앞에서 이미 설명하였고 그 외의 변수들은 식(4) 식(6)으로 설명되어진다.

식(3), 식(4)로부터 표준 상태의 시스템 내 R404 A 과열도와 R404 A/R744 증발온도가 증가함에 따라 $h_{6}$ 가 증가하고, $\mathrm{R} 404 \mathrm{~A}$ 과냉도와 내부열교환기 효율이 증가 함에 따라 $h_{5}$ 가 감소하여 $\left(h_{6}-h_{5}\right)$ 의 값은 커지고, 따 라서 질량유량비는 감소하게 된다. 또한, R404 A 응축 온도가 증가함에 따라 $h_{5}$ 는 증가하고, 캐스케이드 열 교환기 온도차가 증가함에 따라 $h_{6}$ 는 감소하여 질량유 량비는 증가하게 된다.

식(6)에서 알 수 있듯이, 질량유량비의 증감에 따라 압축일량도 증감하게 된다. 따라서, 식(6), 식(7)로부터 질량유량비가 증가하면 $\mathrm{COP}$ 가 감소하고, 질량유량비 가 감소하면 $\mathrm{COP}$ 는 증가하게 된다.

\section{5 다중회귀분석}

이상에서 R744를 사용하는 내부열교환기 부착 R404A 냉동시스템의 여러 변수들의 변화에 따른 영향에 대하 여 알아보았다. 이에, 최적의 열역학적 설계 변수 설정 을 위한 가이드로서 수학적 방정식이 필요하다.

다중회귀분석을 통하여 여러 입력 변수들(R744와 $\mathrm{R} 404 \mathrm{~A}$ 의 과냉도, 과열도, R744 증발온도, R404 A 응축온 도, 캐스케이드 열교환기 온도차, 내부열교환기 효율, 압축 효율)에 대한 함수로써 성능계수(COP)와 최적 질량유량비 $\left(\left(m_{R 404 A} / m_{R 744}\right)_{o p t}\right)$ 에 대한 식을 다음과 같이 도출하였다. 


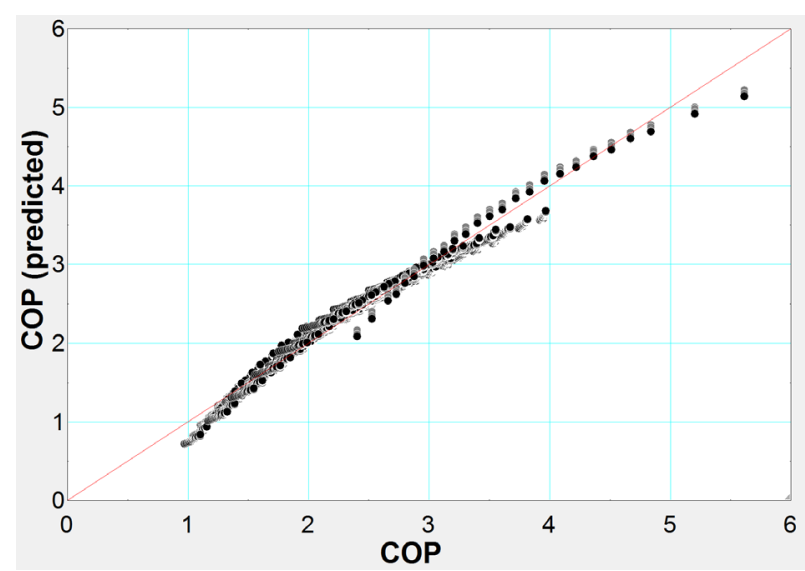

Fig. 8 Comparison between predicted and analysed COP.

$$
\begin{aligned}
\mathrm{COP}= & a_{0}+a_{1} \eta_{c}+a_{2} \eta_{I H X}+a_{3} T_{R 404 A, \text { con }} \\
& +a_{4} \Delta T_{R 404 A, \text { suc }}+a_{5} \Delta T_{R 404 A, \text { suh }} \\
& +a_{6} T_{R 744, e}+a_{7} \Delta T_{R 744, \text { suh }} \\
& +a_{8} \Delta T_{R 744, \text { suc }}+a_{9} \Delta T_{\text {cas }}
\end{aligned}
$$$$
\begin{aligned}
\left(m_{R 404 A} / m_{R 744}\right)_{o p t}= & a_{0}+a_{1} \eta_{c}+a_{2} \eta_{I H X}+a_{3} T_{R 404 A, \text { con }} \\
& +a_{4} \Delta T_{R 404 A, \text { suc }}+a_{5} \Delta T_{R 404 A, \text { suh }} \\
& +a_{6} T_{R 744, \text { e }}+a_{7} \Delta T_{R 744, \text { suh }} \\
& +a_{8} \Delta T_{R 744, \text { suc }}+a_{9} \Delta T_{\text {cas }}
\end{aligned}
$$

데이터는 $2,812,500$ 개에서 5,125 개로 간추려서 분석 하였고, 식(8), 식(9)의 회귀분석 계수 $\left(a_{0} \sim a_{9}\right)$ 와 통계지 표(표준오차, 오차항의 표준편차 $(\mathrm{rms})$, 결정계수 $\left(\mathrm{R}^{2}\right)$ 는 Table 3에 정리하였다.

Table 3 Statistical information for Equations ${ }^{(8)-(9)}$

\begin{tabular}{c|c|c|c|c}
\hline \multirow{2}{*}{} & \multicolumn{2}{|c}{$\begin{array}{c}\text { Linear regression coefficients } \\
\text { for COP }\end{array}$} & \multicolumn{2}{c}{$\begin{array}{c}\text { Linear regression coefficients } \\
\text { for }\left(m_{R 404 A} / m_{R 744}\right)_{o p t}\end{array}$} \\
\cline { 2 - 5 } & Value & Standard error & Value & Standard error \\
\hline a0 & 4.2862 & 0.01722 & 1.7092 & 0.00683 \\
\hline a1 & 2.9367 & 0.00887 & -0.0011 & 0.00352 \\
\hline a2 & 0.1826 & 0.00887 & -0.5711 & 0.00352 \\
\hline a3 & -0.0482 & 0.00021 & 0.0131 & 0.00008 \\
\hline a4 & 0.0207 & 0.00021 & -0.0123 & 0.00008 \\
\hline as & 0.0013 & 0.00021 & -0.0031 & 0.00008 \\
\hline a6 & 0.1076 & 0.00050 & -0.0160 & 0.00020 \\
\hline a7 & -0.0020 & 0.00050 & 0.0083 & 0.00020 \\
\hline a8 & -0.0020 & 0.00050 & 0.0140 & 0.00020 \\
\hline a9 & -0.1128 & 0.00144 & -0.0005 & 0.00057 \\
\hline & \multicolumn{2}{|c|}{$\begin{array}{l}\text { Number of points(n) }=5,125 \\
\text { rms }=0.10174\end{array}$} & $\begin{array}{l}\text { Number of points(n) }=5,125 \\
\text { rms }=0.04037 \\
\mathrm{R}^{2}=94.21 \%\end{array}$ \\
\hline
\end{tabular}

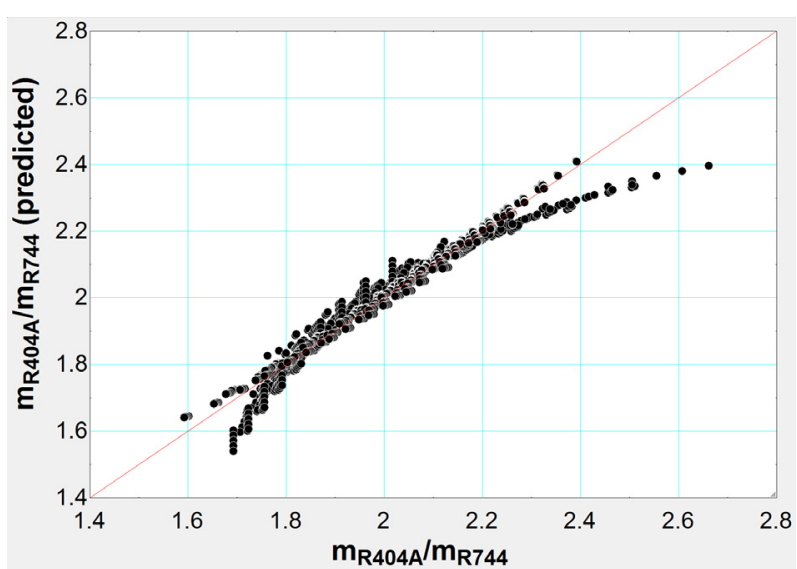

Fig. 9 Comparison between predicted and analysed $\mathrm{R} 404 \mathrm{~A}$ and R744 mass ratios.

Fig. 8과 Fig. 9는 $\mathrm{COP}$ 와 질량유량비에 대한 분석값과 식(8), 식(9)에 의한 예측값을 비교한 그래프이다. Fig. 8 과 9 에서 알 수 있듯이 $\mathrm{COP}$ 는 $\pm 5 \%$ 이내에서 만족 하였고 $\left(m_{R 404 A} / m_{R 744}\right)_{o p t}$ 는 $\pm 10 \%$ 이내에서 만족함을 알 수 있다.

\section{4. 결 론}

R744를 사용하는 내부열교환기 부착 R404A 냉동시 스템의 여러 변수들의 변화에 따른 $\mathrm{COP}$ 와 질량유량비 에 대해 알아보았으며, 이에 대한 결과들을 요약하면 다음과 같다.

(1) R744 과냉도와 과열도는 $\mathrm{COP}$ 와는 무관하며 과 냉도와 과열도가 적을수록 질량유량비가 작게 나왔다. 그리고 R404A 루프의 과냉도와 과열도 가 클수록 $\mathrm{COP}$ 가 크게 나왔으며 질량유량비도 작게 나타났다.

(2) $\mathrm{R} 744 / \mathrm{R} 404 \mathrm{~A}$ 증발온도가 높을수록 $\mathrm{COP}$ 가 높게 나오며 질량유량비는 낮게 나타났다. 그리고 캐 스케이드 열교환기의 온도차와 R404A 응축온도 가 높을수록 $\mathrm{COP}$ 는 낮게 나왔으며 질량유량비 가 크게 나타났다.

(3) 내부열교환기의 효율이 높을수록 $\mathrm{COP}$ 가 높으며 질량유량비는 작게 나타났다. 그리고 압축효율 이 높을수록 $\mathrm{COP}$ 는 높게 나타났으나 질량유량 비는 일정하였다.

(4) R744 과냉도와 과열도, 압축효율을 제외한 다른 변수들의 영향에서 질량유량비가 증가하면 압축 일량도 증가하며, $\mathrm{COP}$ 는 감소하는 것으로 나타 났다. 


\section{후 기}

본 논문은 한국연구재단 일반연구자지원 기본유형 I의 “하이브리드형 $\mathrm{CO}_{2}$ 캐스케이드 냉동시스템 개발(2012 0002181)" 사업의 지원에 의해 수행되었으며, 이에 감 사드립니다.

\section{참고문헌}

1. Reyayan, O. and Behbahaninia, A., 2011, Thermoeconomic optimization and exergy analysis of $\mathrm{CO}_{2} / \mathrm{NH}_{3}$ cascade refrigeration systems, Energy, Vol. 36, pp. 888-895.

2. Wang, K., Eisele, M., Hwang, Y., and Radermacher, R., 2010, Review of secondary loop refrigeration systems, International Journal of Refrigeration, Vol. 33, pp. 212-234.

3. Sawalha, S., 2008, Theoretical evaluation of transcritical $\mathrm{CO}_{2}$ systems in supermarket refrigeration. Part I : Modeling, simulation and optimization of two system solutions, International Journal of Refrigeration, Vol. 31, pp. 516-524.

4. Lim, H. Y., Choi, Y. D., Kim, Y. C., and Kim, M. S., 2003, Development of a new correlation for the heat transfer coefficient of turbulent supercritical car- bon dioxide flow, Society of air-conditioning and refrigerating engineers of Korea, Vol. 15, No. 4, pp. 274-286.

5. Choi, Y. C., Kang, B. H., and Kim, S. H., 2004, An experimental study on heat transfer and pressure drop characteristics during supercritical process of carbon dioxide in a horizontal tube, Society of air-conditioning and refrigerating engineers of Korea, Vol. 16, No. 5, pp. 414-420.

6. Son, C. H., Lee, D. G., Kim, Y. L., and Oh, H. K., 2004, Evaporative heat transfer characteristics of carbon dioxide in a horizontal tube, Society of air-conditioning and refrigerating engineers of Korea, Vol. 16, No. 12, pp. 1134-1139.

7. Park, S. N. and Kim, M. S., 2001, A study on autocascade refrigeration system using carbon dioxide and R134a mixture, International Journal of Air-conditioning and Refrigeration, Vol. 9, No. 1, pp. 39-49.

8. Veiby, O. J., 2003, Internal Records, Documentation in the ICA Supermarket Chain in Norway 2003, Oslo, Norway.

9. 1993, Sintef Vedleggsrapport til STF11 A93051 Brukeroversikt-Kuldmedier I Norge, SNTEF report no. STF11 F93058, Trondheim, Norway. 